\title{
THE NECK-RING GRAVE IN THE CEMETERY OF KLIN-YAR AND ITS PLACE IN THE HIERARCHY OF PRIVILEGED WOMEN'S BURIALS FROM THE GREAT MIGRATION PERIOD IN THE NORTH CAUCASUS
}

\author{
A N N A M A S T Y KO V A
}

This paper analyses the social rank of a privileged woman's burial containing a neck-ring and gold ornaments, investigated in the cemetery of Klin-Yar in the North Caucasus (Stavropol region, near the modern city of Kislovodsk). This rare neck-ring with the medallion featuring the inlay style, surely of 'high-status' nature, indicated the high social rank of its owner. Parallels to this neck-ring with inlay medallion occurred in the 'princely' grave of Bol'shoi Kamenets in the Middle Dnieper area, as well as in Wrocław-Rędzin in modern Poland (this find context remained obscure). The Klin-Yar burial is the only woman's grave from the Great Migration Period in the central North Caucasus connectable to the supreme category of privileged graves.

Keywords: North Caucasus, privileged burials, Great Migration Period, neck-rings.

This article undertakes an attempt to determine the social rank of rich woman's grave in the cemetery of Klin-Yar (Клин-Яр, Fig. 1; Stavropol region, Russian Federation). This grave, discovered by chance during construction works in 1983 (Fig. 2; Kuznecov 2000; Mastykova 2007), is distinguished by the neckring occurring amidst the grave goods, an extremely rare case for elite women's burials from the Great Migration Period (Loskotová 2012; Tejral 2011, 195-199).

It has been determined that archaic societies used personal attire as identifying symbol of the owner's social status. ${ }^{1}$ Moreover, written sources testify that, in ancient societies, attire of the deceased often corresponded to their social

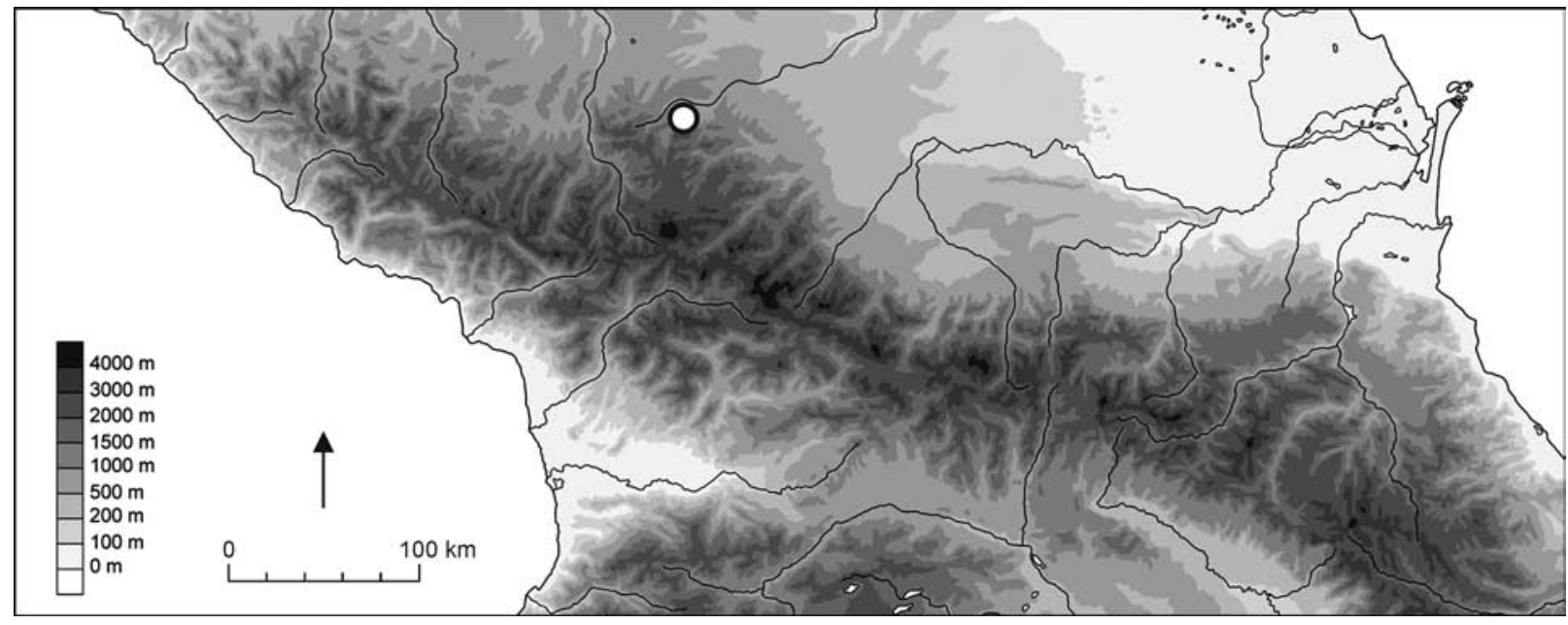

Fig. 1. Klin-Yar cemetery location on the map of the North Caucasus.

\footnotetext{
1 See examples for the Roman and Byzantine Empires at Stout 1994.

2 Let us restrict ourselves to a single example: Moslem writer Ibn Fadlan, who personally witnessed in 922 A.D. the burial of a Rus' leader on the Volga, stated that the Rus' people buried the 'poor' by cremation in a small boat, though for the funeral of the 'rich' (also by boat cremation) they specially made burial cloths. According to Ibn Fadlan's personal observation, these cloths of a rich Rus' person consisted of pants, shoes, a shirt, a brocade kaftan with gold buttons, and a hat with fur trimming. Specifically, they were put on just before the cremation to replace the cloths in which the person died. It is interesting that the slave girl, who was sacrificed during the funeral and was buried together with her master, preliminary took off her ornaments and gave them to the priestess who administered the funeral: there obviously was a clear differentiation of two buried persons by their attire, see Ibn Fadlan, Voyage, 61, 63.
} 


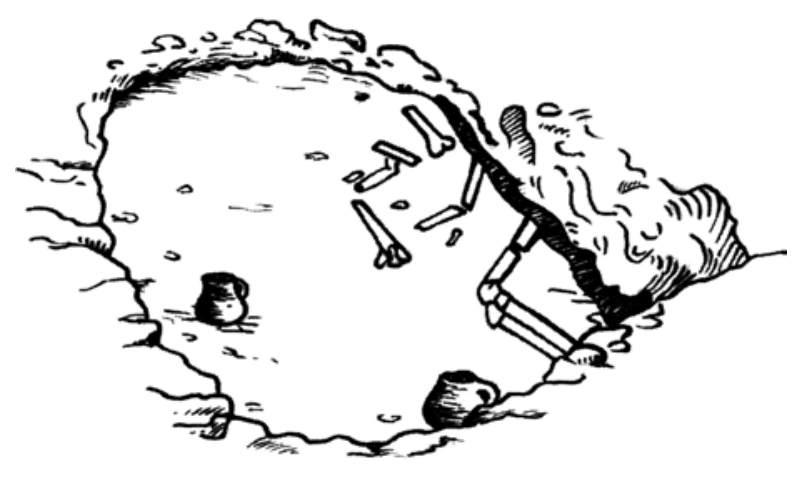

Fig. 2. Remnants of the burial discovered in 1983 (according to Kuznecov 2000, fig. 17: 3).

position. ${ }^{2}$ Women's costume of the North Caucasus population in the Great Migration Period is known basically from grave materials. However, the problem of social interpretation of the data acquired by burial archaeology is among the most complicated, since the correlation principles of 'burial' and actual hierarchy of ancient societies remains a matter of discussion (Brather 2006; Périn 1998; Steuer 1982; 1989). Therefore archaeologists often restrict themselves to making stratification of ancient burials following the level of grave goods wealth, refraining from attributing of determined strata to this or that social group. Especially difficult seems the classification of women's graves since their hierarchy is usually not as pronounced as that of men's graves (see e. g. Périn 1998, 173, 178), among the North Caucasus materials in particular (Korobov 2003, 282, 288).

Nevertheless, archaeologists can find out certain general regularities. Ethnographic parallels and historical data allow us to state that the funeral ritual, as social act, reflected the social structure in this and that way. For Early Mediaeval Europe, with archaeological data partly checkable by written sources, the burials of most noble persons, like graves of historically known kings and queens of the Franks, such as Childeric (Kazanski/Périn 1988; Périn/Kazanski 1996; Quast 2015) or Aregonde (Fleury/
France-Lanord 1979; Périn 2005; 2009; 2012), contained most rich and prestigious grave goods.

Graves of men and women of high social status contained rare and prestigious artefacts, or insignia, indicating their owners' status. ${ }^{3}$ Besides, architecture and location of elite graves clearly indicate their privileged situation. ${ }^{4}$

This way, from all these accounts we have every reason to state that the funeral practice of Early Mediaeval Europe undoubtedly showed the connection between the buried person's social status, wealth and prestige of his/her grave, and its location and architecture. In other words, the higher was the social status of the person buried in 'barbarous' Europe in the Great Migration Period, the richer and more varied were its grave goods.

The same phenomenon occurred in funeral antiquities of proto-historical pre-state societies of Northern Europe, where the wealth degree of grave goods (indicator NAT: Number of Artefact Types) was directly related to the occurrence of rare imported and valuable artefacts of precious metals in graves (Hedeager 1992, 120, 121). Naturally, as every generalizing, this conclusion requires clarifications and reservations. As an example, it has been observed that different wealth of grave goods could be related to different cultural traditions ${ }^{5}$. The age of the dead should also be taken into account, since in traditional societies individual's social position often depended on his/her age (Stauch 2008). This fact is documented, for example, for the case of the peoples of the North Caucasus in the $19^{\text {th }} \mathrm{c}$. (Kazaiev/ Karpeev 2003; Lavrov 1982).

For the case of Merovingian materials, R. Christlein, using wealth and variety of grave goods as a social differentiation criterion, has determined three levels of graves, which general correlation is: Group ' $C$ ' to 'elite', Group ' $B$ ' to the 'middle class', and Group 'A' with the 'poor' (Christlein 1973). Although this system provoked some objections, particularly where it concerned particular interpretations (Brather 2006; Steuer 1982; 1989), it was successfully used not only for Germany, but also for other regions of the Merovingian Kingdom. Later on, Level 'D' was set

\footnotetext{
3 Thus, for example, the grave of King Childeric died in 481 or 482 A.D., contained the following 'high-status' goods: his personal signet-ring, Roman gold T-shaped brooch of a high-ranking official Childeric was the governor of province Belgica II, gold 'royal' bracelet with flaring ends, and sword with gold-plated hilt. The grave of Queen Aregonda also contained her personal gold signet-ring, which allowed to determine the name of the deceased (Die Franken 1996, 936-938, kat. VI. 2.10e).

4 Thus, the grave of King Childeric was most likely covered by a big mound, or there was free space with no other grave around it (Müller-Wille 1997, 248, fig. 3). The grave of Queen Aregonda was discovered in St Denis Church, where the royal family members and their retinue were buried (Fleury/France-Lanord 1979; Fleury/Leproux/Sandron 1996, 57-70).

5 For example, in Northern Gallia 'rich' grave goods except for privileged elite graves in churches, were not typical of urban population (Périn 1998). In Southern and Eastern Gallia, the same as in Italy, 'rich' grave goods were typical of Germanic cultural tradition. Burials corresponding to Roman funeral customs and often placed into expensive stone sarcophagi and mausoleums either did not contain parts of attire or were accompanied with a single symbolic artefact: a comb, a spindle whorl, or a buckle (Martin 1988).
} 
out from the privileged graves of Group ' $\mathrm{C}$ ' in the Merovingian zone to unite the above-described royal and 'princely' graves with 'high-status' grave goods (Périn 1998). Similar patterns have been developed for other regions of 'barbaric' Europe, such as the Danube area (Bierbrauer 1989) or Eastern Prussia (Kazanski/Mastykova/Skvortsov 2017).

Using European works as the background, I have tried to establish the hierarchy of North Caucasus women's costume from the Great Migration Period (Mastykova 2009, 159-177). It is obviously understandable that the criteria developed for the Western European materials are not for mechanical application to the North Caucasian case, so one can only use their general principles. Moreover, the work with the North Caucasus materials uncovers that no general pattern is possible for the region, since the peoples living there were at different stages of social evolution and belonged to different cultural traditions. Finally, the social interpretation of women's costume supposed is preliminary, at least as, first, the state of research of the North Caucasus materials is uneven, and, second, the quality of publication of this material is often low, which impedes its use in modern research.

The classification of women's costume from the Central Ciscaucasia (the area between the Upper Kuban and the Upper Terek) by the wealth level considers primarily the presence or absence of metal attire fragments in graves. After them, it takes into consideration:

- metal value (gold, silver, or bronze alloy);

- frequency of appearance of artefacts in funeral context;

- rare imports and 'high-status' artefacts, or insignia;

- co-occurrence in twin burials with 'rich' and 'poor' man's graves;

- in a few cases, topographic position of the grave within the cemetery.

In the beginning, it is important to note that the attempt of using data of the form, construction, and size of graves, and position of the dead body in the grave, does not give any result. Similarly, the materials of the cemeteries of Klin-Yar, Giliach (Гиляч) and Baital-Chapkan (Байтал-Чапкан) uncover that artificial skull deformation also was not a feature of hierarchy (Fig. 3). However, there is no total anthropological research of the $5^{\text {th }}$ and $6^{\text {th }} \mathrm{c}$. finds in the Central Ciscaucasia, therefore the determination of graves with deformed skulls depends on the opinion of archaeologists, who recorded only striking cases of deformation, perhaps not in every case.

For the region under study in general, applying the principles developed on the Western European materials both to the cases of men's and women's graves, I have set out, with account to wealth and variety of grave goods, the same three levels of burials, which are well known in the Western and Central Europe (Mastykova 2009, 171-177):

- Level 1 (corresponding to R. Christlein's Group 'C' or V. Bierbrauer's Category 1) comprises women's and men's burials with most rich and varied grave goods, including gold artefacts ${ }^{6}$, and/ or 'high-status' prestigious artefacts, as well as rare imported items. Importantly, Level 1 of women's graves divided into two categories based on the composition of grave goods: Category $1 \mathrm{a}$ and $1 \mathrm{~b}$.

Category $1 a$ - comprises women's graves containing, apart from gold, primarily 'high-status' grave goods. I will show hereafter that in the Central Ciscaucasia this category comprised only the necklace grave in the cemetery of Klin-Yar.

Category $1 b-$ is women's graves with gold grave goods and no 'high-status' artefacts. This category envelopes almost all the women's burials discovered in the Central Ciscaucasia, since they did not contain international 'high-status' ware. The attire occurring there in most cases included gold Ushaped or polyhedral or wire earrings, gold hinged badges with inlays, most likely of Mediterranean origin, and gold, plausibly Byzantine, brooches and pendants (Mastykova 2009, 173, 174).

This Level 1 also includes men's graves with gold grave goods and prestigious artefacts, primarily imported Byzantine swords (for them, see Kazanski 2001). It is difficult to understand if these swords indicated high status, similarly with such artefacts as gold belt and strap fittings originating

\footnotetext{
${ }^{6}$ High value of this metal and its social importance in Late Antique and Early Mediaeval Europe are well visible from both archaeological and written sources. It has been noticed that the higher social level is of the grave, the more gold it contained. Grave goods of royal and 'princely' graves contained both highly artistic gold ornaments featuring the cloisonné style and relatively simple bracelets of solid gold. Examples could be gold bracelets from princely graves of Apahida and Blučina, weighing 230.2 and 226.7 g respectively (Werner 1980, 5, pl. 5; Martin 1987, 218, pl. 4). For comparison, one can remember that, according to Procopius of Caesarea, in the age of Justinian I annual 'bonus' given to the soldiers from the emperor comprised single gold coin (Procope, Histoire secrète, XXIV. 28). Nominal weight of Late Roman gold solidus was $4.5 \mathrm{~g}$ (Werner 1980, 5). Weight of 'official's' gold T-shaped brooches from the 4th and 5th c. donated by the emperor varied from 20.3 to $163.5 \mathrm{~g}$ (Werner 1980, pl. 1). These numbers allow one to imagine the high value of gold in the $5^{\text {th }}$ and the first half of the $6^{\text {th }} \mathrm{c}$. Gold was prestigious both in the Roman Empire and amidst the barbarians. Among the subjects of the 'Song of Childebrand' ( $8^{\text {th }} \mathrm{c}$.), is how the German king awarded as a symbolic gift a gold bracelet made of the Roman coins, which he obtained from the king of the Huns (Kyhlberg 1986, 71).
} 


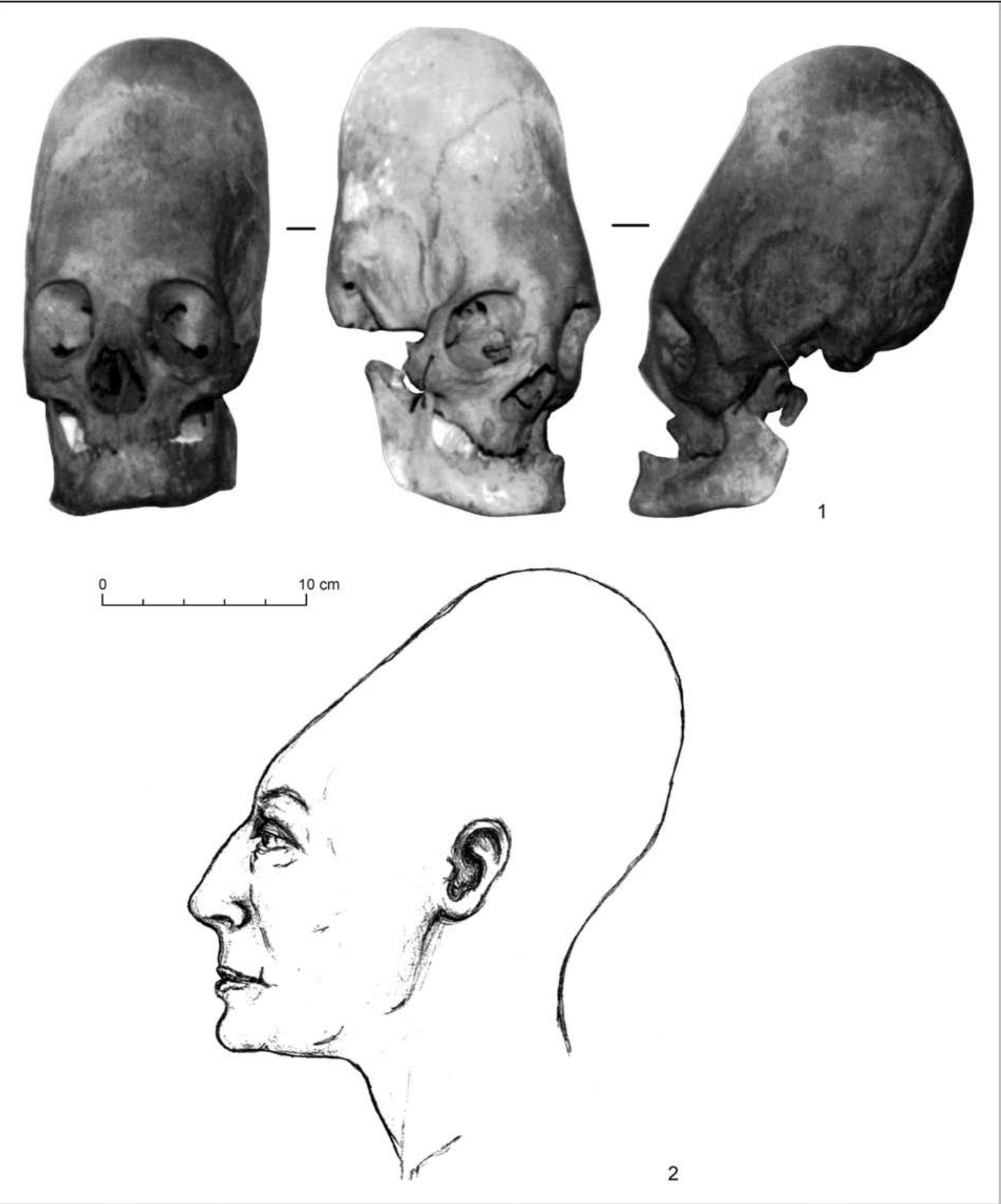

Fig. 3. Skull from the 1983 burial and its reconstruction (according to Mastykova 2007). 1 - according to Kuznecov 2000, fig. 21; 2 - according to Mastykova 2007, fig. 3.

from several graves at this Level. There are a few men's graves of Category 1a: Bylym-Kudinetovo (Былым-Кудинетово), Barrow 14; Bylym-Ozorukovo (Былым-Озоруково), relatable with Merovingian Group 'D', i. e. burials of 'princely' or 'royal' rank (Kazanski/Mastykova 2007, 188).
- Level 2 (corresponding to R. Christlein's Group 'B') comprises burials with ornaments of popular types of inexpensive coloured metals (bronze, rarely silver), in some cases of iron. Imported artefacts in these graves are mostly glass and stone beads. Women's graves of this level correspond to nume- 
rous men's graves with knives or daggers, often accompanied with a belt or, rarely, footwear fittings, accidentally with other types of 'folk' (according to the terminology used by Western European, primarily Scandinavian, archaeologists) weapons, i. e. spears and arrows. A few men's graves at this level contained swords and artefacts which rarely occurred in grave goods, such as metal cauldrons. Perhaps these cases uncover the upper social stratum of this level.

- Level 3 (corresponding to R. Christlein's Group 'A') comprises burials without metal costume fittings, of unclear chronology. They generally correspond to men's graves without knives and belt fittings, with similarly poorly determinable chronology.

It should be taken into account that the general picture would knowingly be incomplete. It poorly would represent 'poor' graves since their chronology and therefore relation to the period in question are very problematic due to inexpressiveness and sometimes lack of grave goods. There were complete social groups probably not represented archaeologically, if their members were buried in a specific place (e. g. elite or priests), or were not buried at all (children younger than a certain age, slaves, etc.).

Correlation of the established levels with some social-and-class groups would be a difficult task, when it comes to North Caucasus populations known from written sources, as a rule, from later period. However, it is still possible to suppose that, similarly to everywhere in Europe, rare burials with rich grave goods of Level 1 corresponds to the highest social class; numerous burials with 'common' set of ornaments of Level 2 correspond to the 'middle class'; and finally, burials of Level 3 belong to 'inferior' society members (some categories of children, socially-dependent individuals, marginal groups, etc.).

So then, let us return to the woman's grave in the cemetery of Klin-Yar on the North Caucasus, the only in the central zone of the North Caucasus corresponding to Category 1a. The burial was made into a catacomb, with the dead woman laying on her right side, in a flexed position (Fig. 2); her skull keeps traces of artificial deformation (Fig. 3). ${ }^{7}$ The grave goods (Fig. 4-6) accompanying her comprised a neck-ring with medallion, a circular gilt bronze badge, brooches, pendants, belt and/or shoe fittings, bracelets, earrings, toilet artefacts (mirrors and tweezers), a circular bi-partite box, ceramic vessels, jewellery box remnants, a knife, and cakeshaped resin-like matter, that appeared to be opium (Kuznecov 2000, 174-183). Two brooches discovered in the grave (Fig. 4: 3,4) under study suggest the chronology from the Post-Hunnic Period, more precisely from the middle-second half of the $5^{\text {th }} \mathrm{c}$. (Mastykova 2007). Let us point out that, apart from various silver and bronze artefacts, the burial contained a bracelet and earrings of gold (Fig. 4: 6; 5: 6), a circular gilt bronze badge with five insets of red garnet and inlays (of red and green glass; Fig. 4: 2), and also imported gilt belt fittings featuring the inlay style, obviously of Mediterranean origin (Fig. 5: 13; 6: 1, 2). Among these fittings there are end-pieces featuring four-petal decoration (Fig. 5: 13), typical of the goods of the Mediterranean tradition (cf. Arrhenius 1985, fig. 69; 103; 106; 108; $186 ; 189)$. Besides, the catacomb contained a chalcedonic bead of ellipsoid form (Fig. 6: 4). These beads formed a part of prestigious woman's costume of prosperous population, being a social marker; in the second third of the $5^{\text {th }} \mathrm{c}$., they also occurred in the 'aristocratic' costume on the Danube (Mastykova 2006). Finally, this grave, among the listed gold and prestigious imported ware, contained a bronze neck-ring (or head hoop?), plated with gold foil and decorated with a gold medallion decorated with plique-à-jour style (Fig. 4: 1).

The 'princely' women's attire of the European Barbaricum from the Great Migration Period almost never contained neck-rings, apart from the find in the woman's grave in Levice-Kusá Hora, in modern Slovakia (Loskotová 2012; Tejral 2011, 195-199), and perhaps in Bol'shoi Kamenets (Большой Каменец), on the left bank of the Dnieper. However, in this period they were typical of the costume of military leaders (Matsulevich 1934, pl. IX). Admittedly, men's torque-like neck-rings seem far simple: they were made of gold rods without polychrome decoration, similarly to the Klin-Yar neck-ring.

So far there are known only two parallels to the Klin-Yar neck-ring, both of the group of 'princely' finds from the Great Migration Period in the Eastern and Central Europe. The first is the gold neck-ring from Wrocław-Rędzin in modern Poland (Fig. 7: 1), tentatively related to the final stage of the Przeworsk Culture in the Period D1 of the 'barbarian' timeline: 360/370-400/410 A.D. (Burschel Kowalski/Rogalski 2017, cat. no. 40; Mączyńska 1999, 152, fig. 10: 1).

Although the find context in this case remains obscure, the making of the neck-ring of gold, which

\footnotetext{
7 Its portrait reconstruction has been made by Galina Lebedinskaia and Maria Mednikova. I am indebted to them for their kind permission to publish this reconstruction.
} 


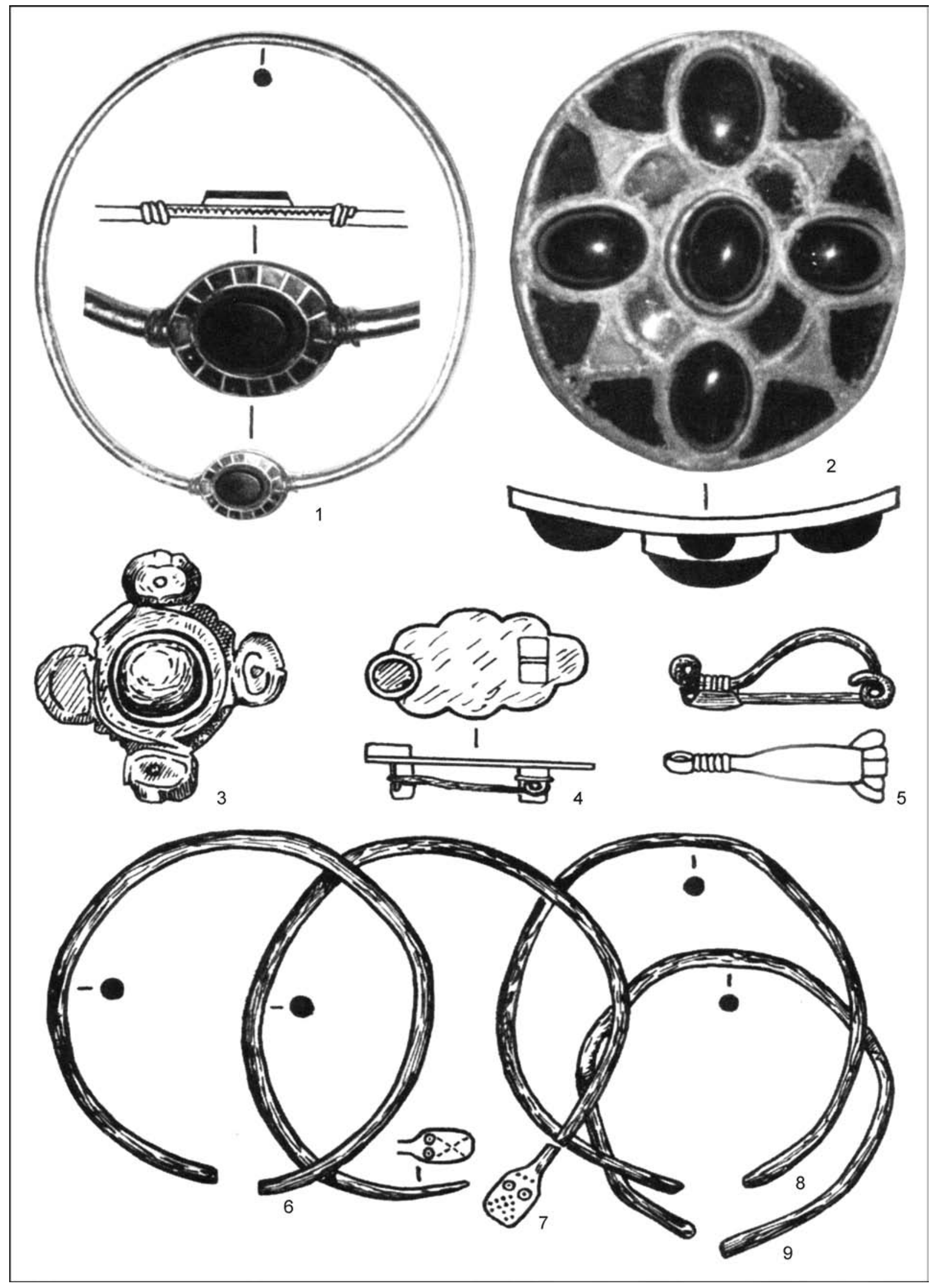

Fig. 4. Grave goods from the 1983 burial in the cemetery of Klin-Yar (according to Kuznecov 2000, fig. 18). 

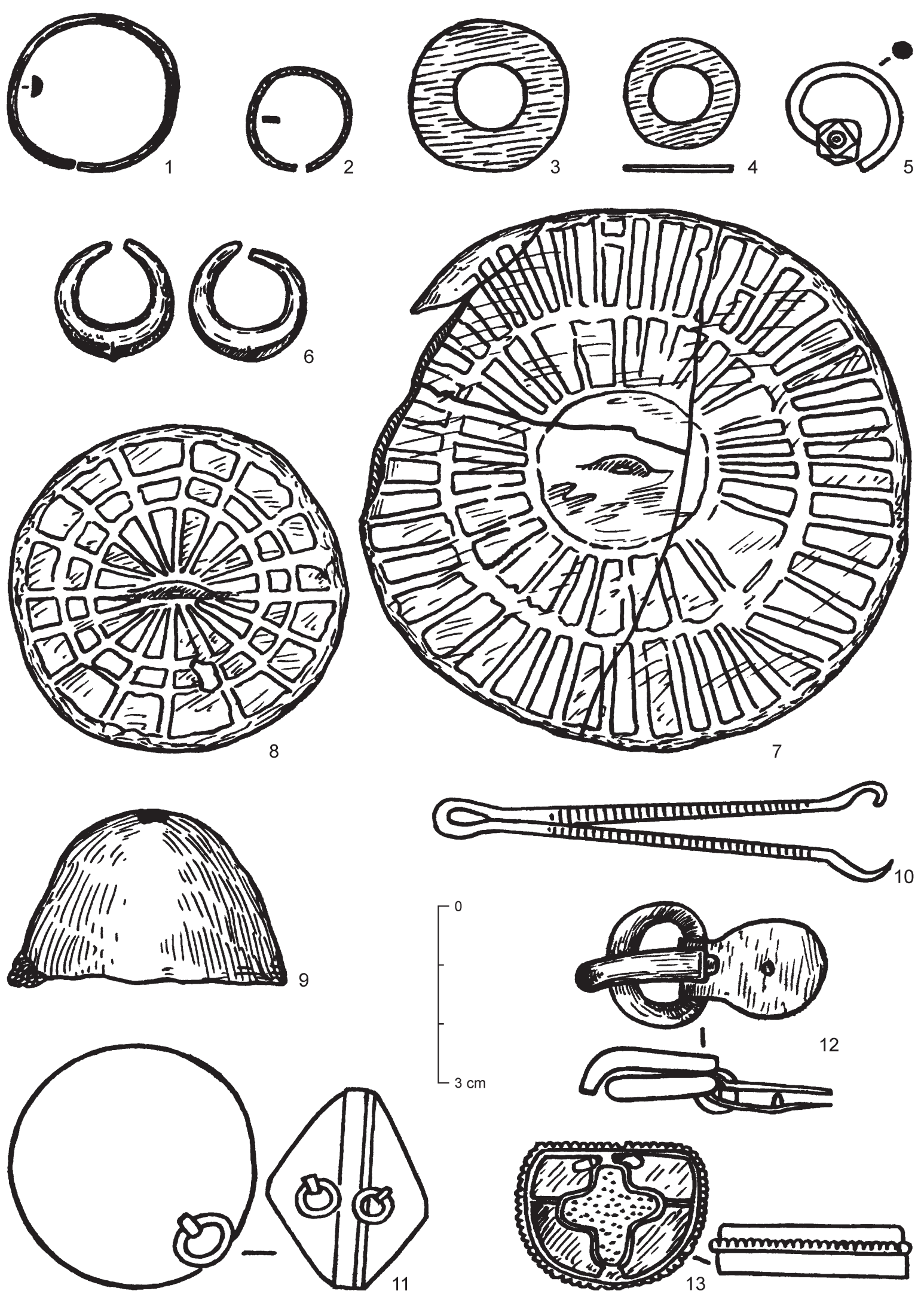

Fig. 5. Grave goods from the 1983 burial in the cemetery of Klin-Yar (according to Kuznecov 2000, fig. 19). 

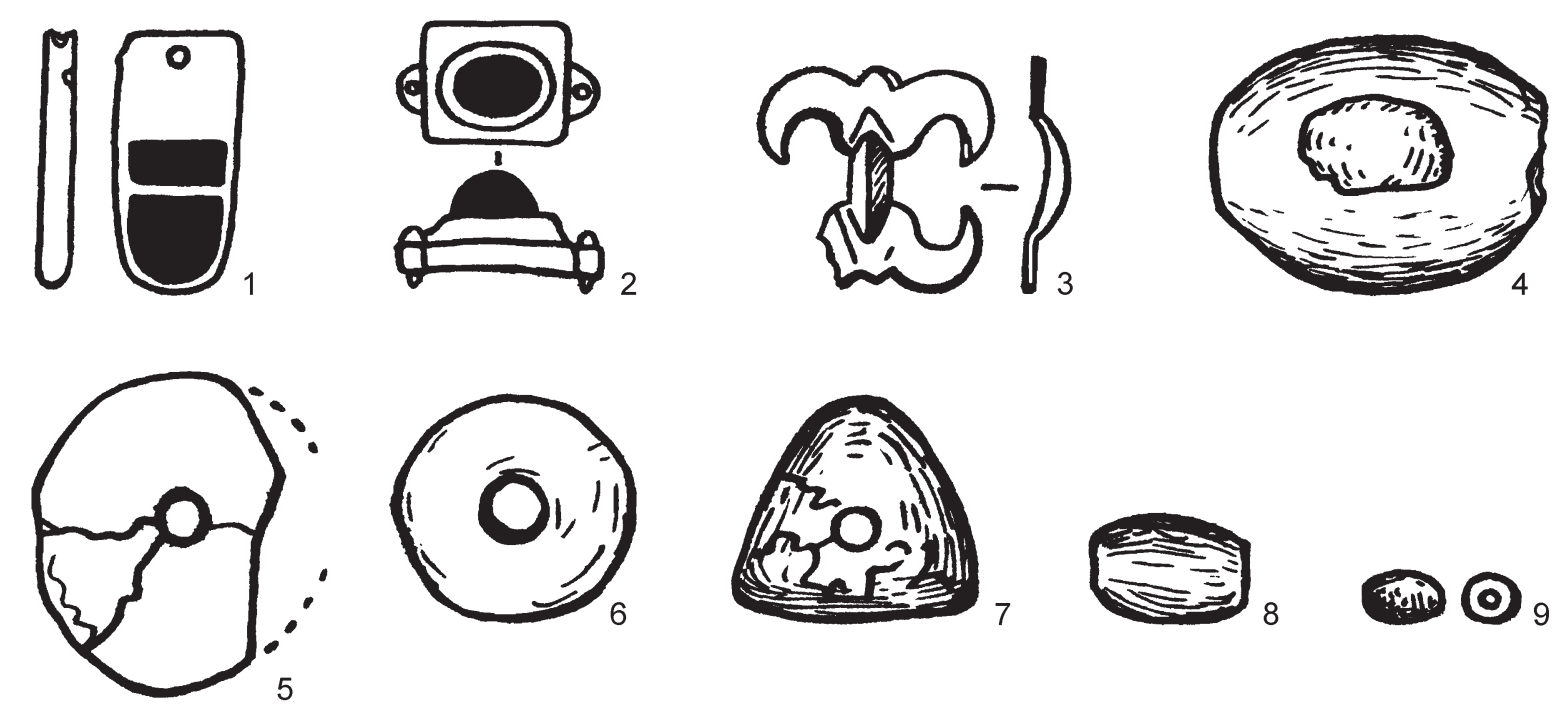

Fic 19

$\bigcirc \odot_{10} \quad \mathbb{1 B} \odot_{11} \quad \mathbb{O} \oslash_{12} \quad \square \odot_{13} \quad 000 \odot_{14}$ (2)
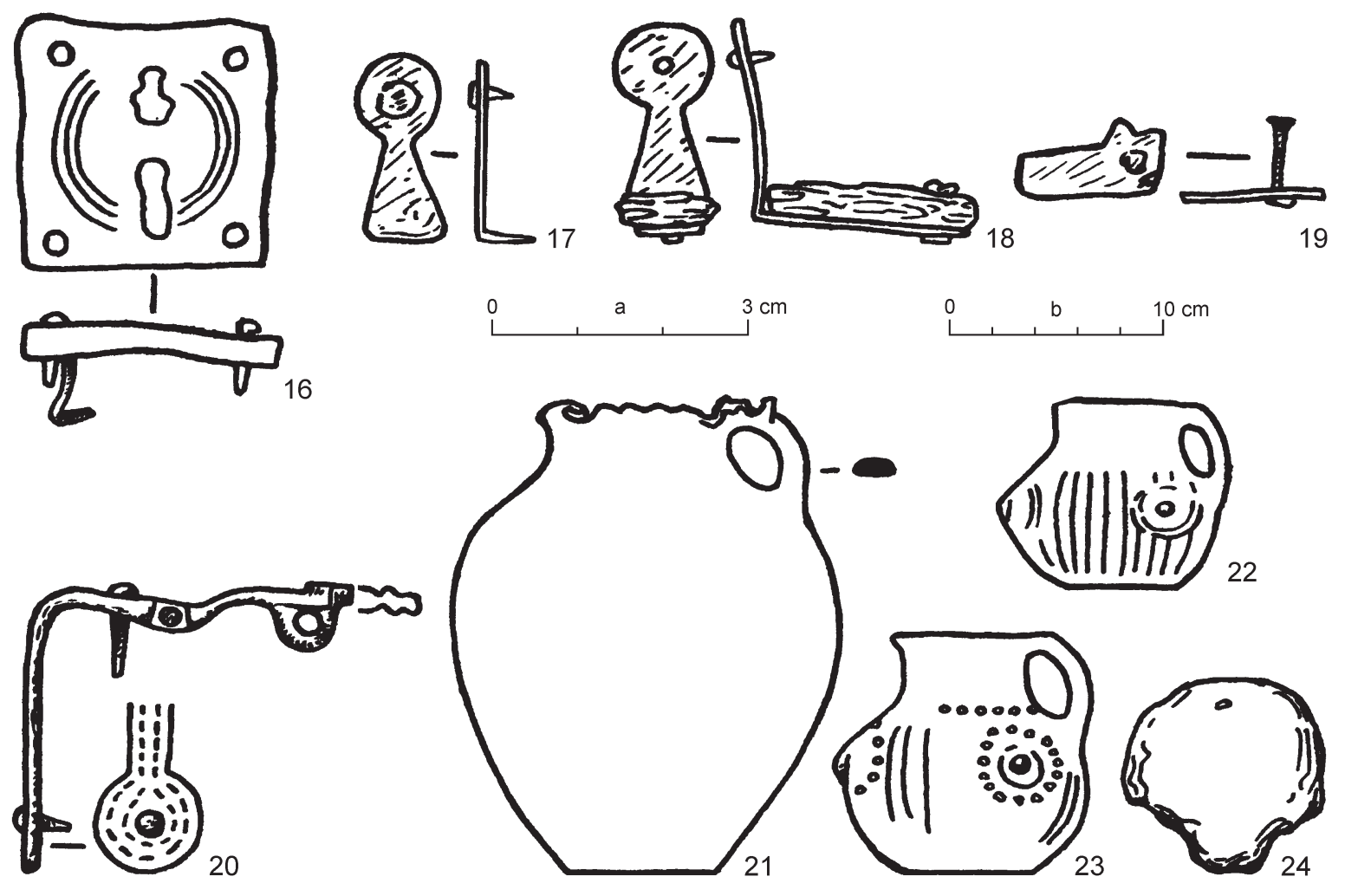

Fig. 6. Grave goods from the 1983 burial in the cemetery of Klin-Yar (according to Kuznecov 2000, fig. 20). Scale: a - 1-20, 24; $b-21-23$. 

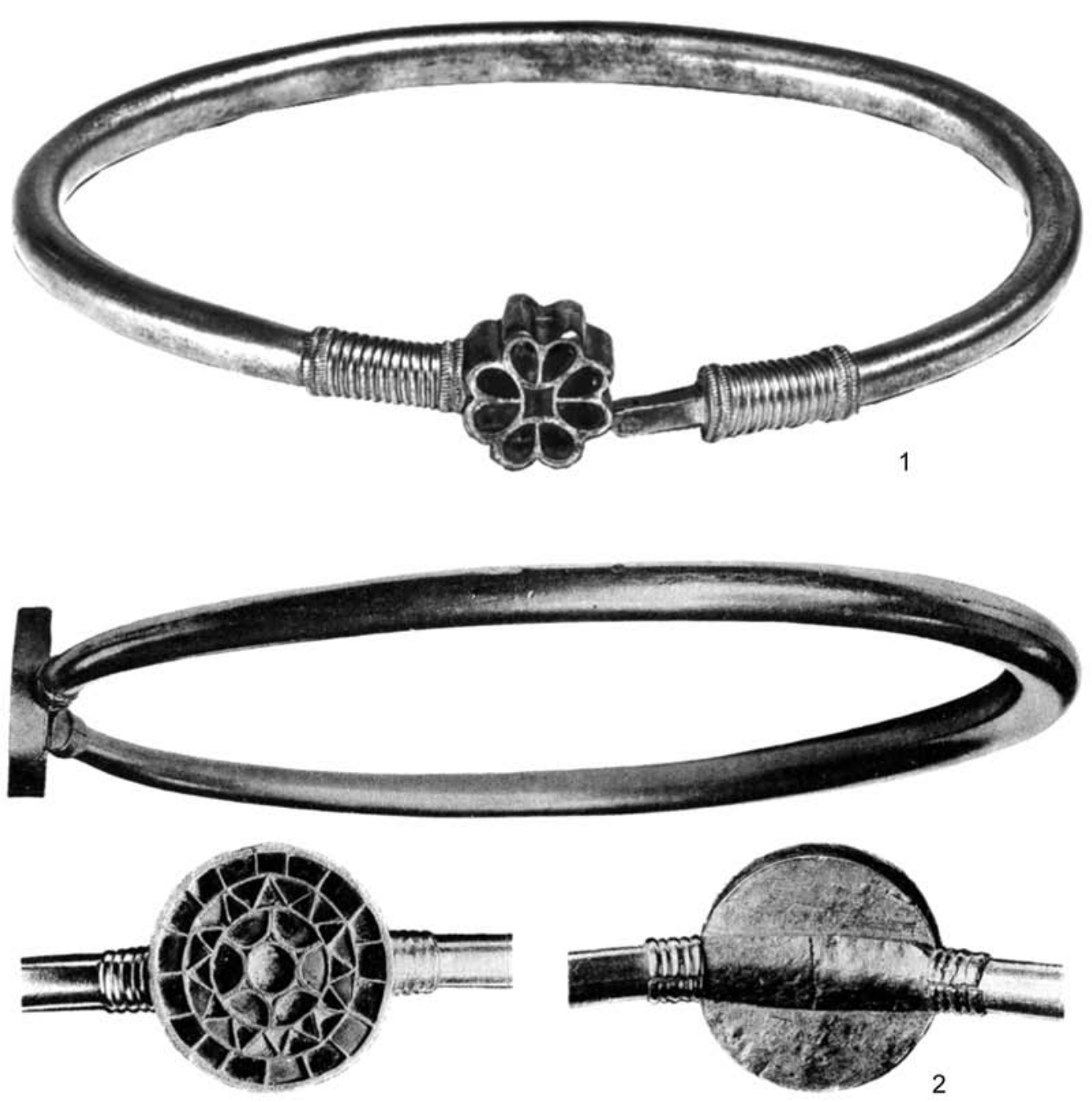

Fig. 7. Parallels to the neck-ring from the cemetery of Klin-Yar. 1 - Wrocław-Rędzin; 2 - Bol'shoi Kamenets, 1918-1927 burial. 1 - according to Bursche/Kowalski/Rogalski 2017, cat. no. 40; 2 - according to Matsulevich 1934, pl. IX).

was generally rare in the modern Poland territory in the Great Migration period, gives reasons to interpret this find as 'princely'. Another gold neck-ring featuring the medallion of plique-à-jour inlay style (Fig. 7: 2) was found in a 'princely', perhaps woman's, grave in Bol'shoi Kamenets, which contained a set of supplementary gold ornaments from the Hunnic Period (Kazanski/Mastykova 2016, 86, 87). A parallel to the decoration of the medallion of the neck-rig from Bol'shoi Kamenets could be the medallion found in the cemetery of Luchistoe (Дучистое) in the Crimea, also dated to the Hunnic Period (Aibabin/ Hairedinova 1998, fig. 13: 10). Additional ornaments of gold chains, accompanying the Bol'shoi Kamenets neck-ring, are typical of the $5^{\text {th }} \mathrm{c}$. 'princely' burials, such as Untersiebenbrunn, Airan, Hochfelden, Kluj-Someşeni, and Apahida (see examples at $L^{\prime} O r$ des princes barbares 2000).

The gilt neck-ring from the woman's grave in the cemetery of Klin-Yar has an oval gold medallion featuring the inlay style with geometric patterns (Fig. 4: 1). This medallion, similarly to the medallion in the neck-ring from Bol'shoi Kamenets, belongs to the group of artefacts of the Late Roman tradition (Fig. 8), of the so-called N. Adams' Style B (Adams 2000, 29, 55, fig. 2). ${ }^{8}$ Perhaps these ornaments (and plausibly also the neck-ring from Wrocław-Rędzin) were made in the same Mediterranean or Near Eastern workshop to reflect common Mediterranean fashion.

\footnotetext{
8 However, similar are ornamental motifs on Sasanian ware, and ornaments from the Transcaucasia and Central Asia (Fig. 8: 1-3; Adams 2000, pl. V: 1, 3, 5, 7; XII: 3, 4).
} 


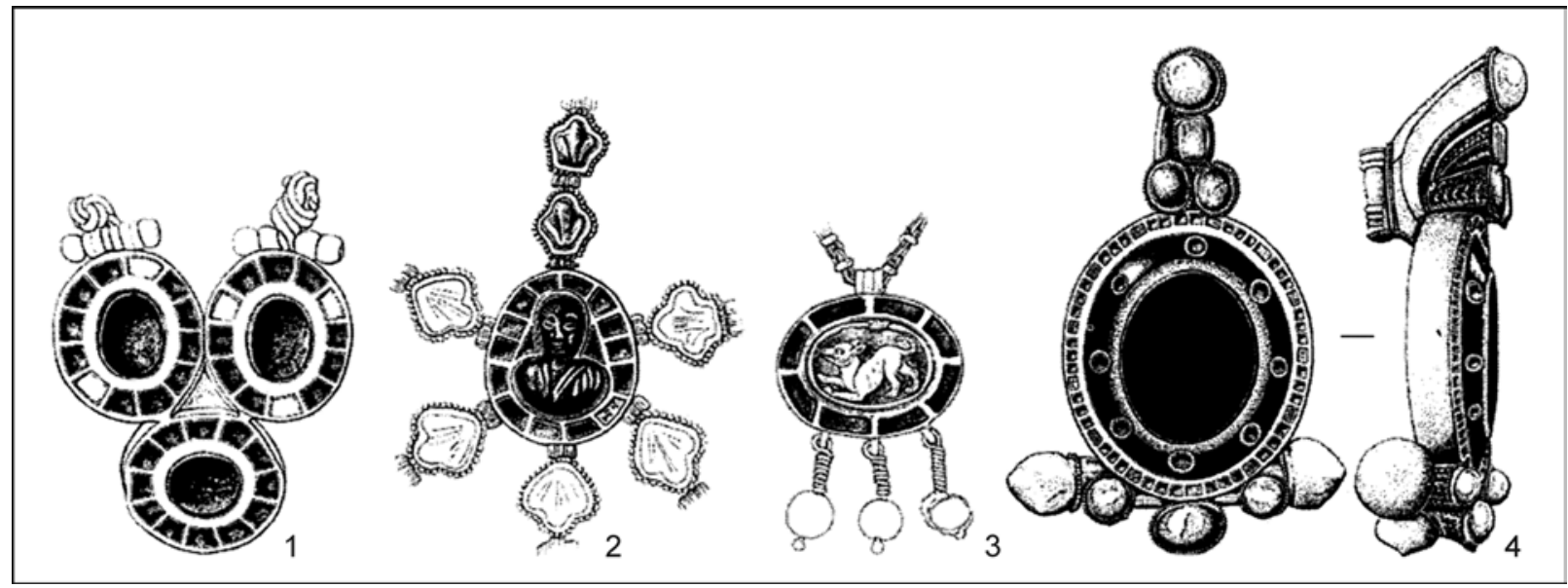

Fig. 8. Artefacts with inlays featuring Style B (according to Adams 2000). 1 - Hatra (Iraq); 2 - Shamsi (Kirghizia); 3 - Armaziskhevi (Georgia); 4 - Simleul Silvaniei (Romania; according to Mastykova 2007, fig. 10).

According to iconographic data from the Late Roman and Early Byzantine Periods, women's neck-rings, particularly those with medallions, often appeared in the Eastern Mediterranean (see the portrait of a woman from Antinoe in Egypt, as well as images on Coptic textiles - Rutschowscaya 1990, 49, 51, 77, 85).

Neck-rings with rounded inlay medallions were known among the Germanic antiquities in Central and Northern Europe already in the Late Roman Period. We can remember such 'princely' finds as Cejkov in Slovakia (Beninger 1931, pl. 8: 2h), Dorotowo in Polish Pomerania (La Baume 1934, pl. 64: k), and Ravlunda in Sweden (Andersson 1993, no. 965; fig. 60; 1995, 88, fig. 60, 61; Arrhenius 1985, fig. 89). They could be the prototypes for the neck-rings from the Great Migration Period.

The rare neck-ring with a medallion featuring inlay style from the woman's burial in Klin-Yar obviously had 'high-status' nature, indicating its owner's advanced social rank. It is quite probable that the neck-ring in the given context bore the same symbolic function as, for example, the diadem of Empress Theodora, the precious shoulder ornament being a part of imperial insignia. According to the proposed gradation of the North Caucasus women's costume and the composition of the grave goods, the burial in the cemetery of Klin-Yar relates to Category 1a at Level 1, i. e. the group of burials containing gold and 'high-status' grave goods.

There is no doubt that the Klin-Yar burial did not contain so many precious artefacts and insignia as royal graves in Tournai, Blučina, or Apahida. The Klin-Yar grave certainly belonged to a lower rank. The neck-ring discovered there was made, but its gold medallion, of bronze plated with gold foil to be rather an imitation of expensive high- status artefact. However, this grave should be analysed against the background of the definite funeral context of the Northern Caucasus, which generally was more modest than Roman-Germanic Western and Central Europe. Considering the local background, there would be no doubt concerning the privileged nature of the grave in question. It is also important that this grave was uncovered in the cemetery in Piatigor'e area, where a centre of power of North Caucasus Alans in the $5^{\text {th }}$ and $6^{\text {th }} \mathrm{c}$. has been supposed, and the site itself, comprising the cemetery and a fortified settlement located nearby, possesses an especially important place there (Korobov 2017, 296, 297).

In conclusion, it is important to underline that the fashion of high social classes of the Eastern Roman Empire made a decisive impact on the shaping of the culture of barbarian aristocracy in the North Caucasus in the $5^{\text {th }}$ and $6^{\text {th }}$ c. (Kazanski/Mastykova 1999; 2007; Mastykova 2009, 122, 123). The influence of this fashion occurs in the attire of noble woman buried in Klin-Yar, as indicated by such elements of her costume as the above-mentioned gilt belt fittings featuring the Mediterranean inlay style (Fig. 5: 13; 6: 1, 2), two brooches having Mediterranean prototypes (Fig. 4: 3, 4; Mastykova 2009, 37), and circular metal bi-partite box typical of women's costume of Mediterranean tradition (Fig. 5: 11; Mastykova 2009, 87; Vida 1995). Rich attire from the privileged woman's grave in Klin-Yar should be analysed within the context of the Mediterranean fashion. It has already been stated that all the conclusions made above were nothing but preliminary. The place of the Klin-Yar grave in the social hierarchy of the North Caucasus burials will possibly be clarified following the publication of all the archaeological materials obtained by that moment. 


\section{LITERATURE}

Adams 2000 - N. Adams: The development of Early garnet inlaid ornaments. In: C. Bálint (Hrsg.): Kontakte zwischen Iran, Byzanz und der Steppe im 6.-7. Jahrhundert. Budapest 2000, 13-70.

Aibabin/Hairedinova 1998 - A. Aibabin/E. Hairedinova: Rannie kompleksy mogilnika u sela Luchistoe v Krymu. Materialy po Arheologiy Istorii i Ètnografii Tavrii 6, 1998, 274-311.

Andersson 1993 - K. Andersson: Romartida Guldsmide i Norden I. Katalog. Uppsala 1993.

Andersson 1995 - K. Andersson: Romartida Guldsmide i Norden III. Övriga smycken, teknisk analys och verkstadsgrupper. Uppsala 1995.

Arrhenius 1985 - B. Arrhenius: Merovingian Gamet Jewellery. Stockholm 1985.

Beninger 1931 - E. Beninger: Der Wandalenfunde von Czeke-Cejkov. Annalen des Naturhistorisches Museum 45, 1931, 182-224.

Bierbrauer 1989 - V. Bierbrauer: Ostgermanische Oberschichtgräber der römischen Kaiserzeit und des Frühen Mittelalters. Archaeologia Baltica 8, 1989, 39-106.

Brather 2006 - S. Brather: Kleidung, Bestattung, Ritual. Die Präsentation sozialer Rollen im frühen Mittelalter. In: S. Brather (Hrsg.): Zwischen Spätantike und Frühmittelalter. Archäologie des 4. bis 7. Jahrhunderts im Westen. Berlin - New York 2006, 237-273.

Bursche/Kowalski/Rogalski 2017 - A. Bursche/K. Kowalski/B. Rogalski: Barbarzyńskie tsunami. Okres wędrówek ludów w dorzeczu Odry i Wisty. Warszawa - Szczecin 2017.

Christlein 1973 - R. Christlein: Besitzabstufungen zur Merowingerzeit im Spiegel reicher Grabfunde aus West- und Süddeutschland. Jahrbuch des Römisch-Germanischen Zentralmuseums 20, 1973, 147-180.

Die Franken 1996 - Die Franken. Wegbereiter Europas. Band 2. Mainz 1996.

Fleury/France-Lanord 1979 - M. Fleury/A. France-Lanord: Bijoux et parures d'Arégonde. Dossiers de l'archéologie 32, janvier-février 1979.

Fleury/Leproux/Sandron 1996 - M. Fleury/G.-M. Leproux/ D. Sandron: Paris de Clovis à Dagobert. Paris 1996.

Hedeager 1992 - L. Hedeager: Iron-Age Societies. From Tribe to State in Northern Europe, 500 B.C. to A.D. 700. Oxford 1992.

Ibn Fadlan, Voyage - Ibn Fadlan: Voyage chez les Bulgares de la Volga. Translated by M. Canard. Paris 1983.

Kazanski 2001 - M. Kazanski: Les épées 'orientales' à garde cloisonnée du $\mathrm{V}^{\mathrm{e}}-\mathrm{VI}^{\mathrm{e}}$ siècle. In: E. Istvánovits/ V. Kulcsár (eds.): International Connections of the Barbarians in the $1^{\text {st }}-5^{\text {th }}$ centuries A.D. Aszód - Nyíregyháza 2001, 389-418.

Kazanski/Mastykova 1999 - M. Kazanski/A. Mastykova: Le Caucase du Nord et la région méditerranéenne aux $\mathrm{V}^{\mathrm{e}}-\mathrm{VI}^{\mathrm{e}}$ siècles. A propos de la formation de la civilisation aristocratique barbare. Eurasia Antiqua 5, 1999, 523-573.

Kazanski/Mastykova 2007 - M. Kazanski/A. Mastykova: Machtzentren und Handelswege in Westalanien im V.-VI. Jahrhundert. In: J. Tejral (Hrsg.): Barbaren im
Wandel. Beiträge zur Kultur- und Identitätsumbildung in der Völkerwanderungszeit. Brno 2007, 173-197.

Kazanski/Mastykova 2016 - M. Kazanski/A. Mastykova: 'Princely' finds and power centers in Eastern European Barbaricum in the Hunnic time. In: H. Geisler (Hrsg.): Wandel durch Migration? 26. Internationales Symposium 'Grundprobleme der frühgeschichlichen im mittleren Donauraum'. Büchebach 2017, 85-103.

Kazanski/Mastykova/Skvortsov 2017 - M. Kazanski/ A. Mastykova/K. Skvortsov: Priznaki socialnoj stratifikacii u naselenia sambijsko-natangijskoj kultury v nachale srednevekovia (seredina V-VII v.). Rossijskaia Arheologiya 3, 2017, 19-36.

Kazanski/Périn 1988 - M. Kazanski/P. Périn 1988: Le mobilier funéraire de la tombe de Childéric 1er. Etat de la question et perspectives. Revue Archéologique de Picardie 3-4, 1988, 13-38.

Kazaiev/Karpeev 2003 - Sh. Kazaiev/I. Karpeev: Povsednevnaia zhizn gorcev Severnogo Kavkaza v XIX veke. Moskva 2003.

Korobov 2003 - D. Korobov: Socialnaia organizaciia alan Severnogo Kavkaza IV-IX vv. Sankt-Peterburg 2003.

Korobov 2017 - D. Korobov: Sistema rasseleniia alan Centralnogo Predkavkazia v I tys. n. e. 1. Sankt-Peterburg 2017.

Kuznecov 2000 - V. Kuznecov: Deux tombes alaines des $\mathrm{V}^{\mathrm{e}}-\mathrm{VI}^{\mathrm{e}}$ s. à Hasaut et à Klin-Yar. In: M. Kazanski/ V. Soupault (dir.): Les Sites archéologiques en Crimée et au Caucase durant l'Antiquité tardive et le haut Moyen-Age. Leiden 2000, 153-192.

Kyhlberg 1986 - O. Kyhlberg: Late Roman and Byzantine Solidi. An archaeological analysis of coins and hoards. In: Excavations at Helgö X. Coins, Iron and Gold. Stockholm 1986, 13-126.

La Baume 1934 - W. La Baume: Urgeschichte der Ostgermanen. Danzig 1934.

Lavrov 1982 - L. I. Lavrov: Etnografiia Kavkaza (po polevym materialam 1924-1978 gg.). Leningrad 1982.

L'Or des princes barbares 2000 - L'Or des princes barbares. Du Caucase à la Gaule Vé siècle après J.-C. Paris 2000.

Loskotová 2012 - Z. Loskotová: An early $5^{\text {th }}$ century skeleton grave with gold neck-ring from Charváty (Moravia). In: V. Ivanišević/M. Kazanski (eds.): The Pontic-Danubian Realm in the Period of the Great Migration. Paris - Beograd 2012, 189-206.

Mączyńska 1999 - M. Mączyńska: La fin de la culture de Przeworsk. In: J. Tejral/C. Pilet/M. Kazanski (dir.): L'Occident romain et l'Europe centrale au début de l'époque des Grandes Migrations. Brno 1999, 141-170.

Martin 1987 - M. Martin: Redwalds Börse. Gewicht und Gewichtskategorien völkerwanderungszeithcher Objekte aus Edelmetall. Frühmittelalterliche Studien 21, 1987, 206-238.

Martin 1988 - M. Martin: Grabfunde des 6. Jahrhunderts aus der Kirche St. Peter und Paul in Meis SG. Archéologie Suisse 11, 1988, 167-181.

Mastykova 2006 - A. Mastykova: Les grosses perles du haut Moyen Âge en calcédoine et en forme de tonneau: diffusion, datation, signification sociale. 
In: X. Delestre/M. Kazanski/P. Périn (dir.): De l'Age du Fer au haut Moyen Âge. Archéologique funéraire, princes et élites guerrières. Saint-Germain-en-Laye 2006, 234-250.

Mastykova 2007 - A. Mastykova: Grivna iz mogilnika Klin-Yar i vozmozhnosti vydelenia privilegirovannykh zhenskikh pogrebenij epohi Velikogo pereselenia narodov v Centralnom Predkavkaze. In: V. Kozenkova/V. Malašev (red.): Severnyj Kavkaz i mir kochevnikov $v$ rannem zheleznom veke. Sbornik pamiati M. P. Abramovoj. Moskva 2015, 472-490.

Mastykova 2009 - A. Mastykova: Zhenskij kostium Centralnogo i Zapadnogo Predkavkazia v konce IV-seredine VI v. n. e. Moskva 2009.

Matsulevich 1934 - L. Matsulevich: Pogrebenie varvarskogo kniazya v Vostochnoj Evrope. Moskva - Leningrad 1934.

Müller-Wille 1997 - M. Müller-Wille: Les tombes royales et aristocratiques à tumuli. Antiquités nationales 29, 1997, 245-257.

Périn 1998 - P. Périn: Possibilités et limites de l'interprétation sociale des cimetières mérovingiens. Antiquités nationales 30, 1998, 169-184.

Périn 2005 - P. Périn: La tombe d'Aregonde. Nouvelles analyses en laboratoire du mobilier métallique et des restes organiques de la défunte du sarcophage 49 de la basilique de saint-Denis. Antiquités nationales 37, 2005, 181-206.

Périn 2009 - P. Périn: Les tombes mérovingiennes de la basilique de Saint-Denis. In: U. von Freeden/H. Friesinger/E. Wamers (Hrsg.): Glaube, Kult und Herrschaft. Phänomene des Religiösen im 1. Jahrtausend n. Chr. in Mittel- und Nordeuropa. Bonn 2009, 173-183.

Périn 2012 - P. Périn: Die Bestattung in Sarkophag 49 unter der Basilika von Saint-Denis. In: E. Wamers/P. Périn (Hrsg.): Königinnen der Merowinger. Adelsgräber aus den Kirchen von Köln, Saint-Denis, Chelles und Frankfurt. Frankfurt am Main 2012, 101-121.

Manuscript accepted 27. 10. 2019

From Russian translated by Nikita Khrapunov Súhrn preložila Viera Tejbusová
Périn/Kazanski 1996 - P. Périn/M. Kazanski: Das Grab Childerichs I. In: Die Franken. Wegbereiter Europas. Band 1. Mainz 1996, 173-182.

Procope, Histoire secrète - Procope, Histoire secrète. Translated by P. Maraval. Paris 1990.

Quast 2015 - D. Quast (Hrsg.): Das Grab des fränkischen Königs Childerich in Tournai und die Anastasis Childerici von Jean-Jacques Chifflet aus dem Jahre 1655. Mainz 2015.

Rutschowscaya 1990 - M.-H. Rutschowscaya: Tissus coptes. Paris 1990.

Stauch 2008 - E. Stauch: Alter ist Silber, Jugend ist Gold! Zur altersdifferenzierten Analyse frühgeschichtlicher Bestattungen. In: S. Brather (Hrsg.): Zwischen Spätantike und Frühmittelalter. Archäologie des 4. bis 7. Jahrhunderts im Westen. Berlin - New York 2006, 275-295.

Steuer 1982 - H. Steuer: Frühgeschichtliche Sozialstrukturen in Mitteleuropa. Eine Analyse der Auswertungsmethoden des archäologischen Quellenmaterials. Göttingen 1982.

Steuer 1989 - H. Steuer: Archaeology and history: Proposals on the social structure of the Merovingian kingdom. In: K. Randsborg (ed.): The birth of Europe: archaeology and social development in the first millennium A.D. Roma 1989, 100-122.

Stout 1994 - A. M. Stout: Jewelry as a Symbol of Status in the Roman Empire. In: J. L. Sebesta/L. Bonfante (eds.): The world of Roman costume. Madison 1994, 77-100.

Tejral 2011 - J. Tejral: Einhemische und Fremde. Das norddanubische Gebiet zur Zeit der Völkerwanderung. Brno 2011.

Vida 1995 - T. Vida: Frühmittelalterliche scheiben- und kugelförmige Amulettkapseln zwischen Kaukasus, Kastilien und Picardie. Bericht der Römisch-Germanischen Kommission 76, 1995, 219-290.

Werner 1980 - J. Werner: Der goldene Armring des Frankenkönigs Childerich und die germanischen Handgelenkringe der jüngeren Kaiserzeit. Frühmittelalterliche Studien 14, 1980, 1-49.

Dr. hab. Anna Mastykova

Institute of Archaeology

19 Dimitrii Ulianov Str.

RU - 117036 Moscow

amastykova@mail.ru 


\title{
Hrob s nákrčníkom na pohrebisku Klin-Jar a jeho miesto $\mathrm{v}$ hierarchii hrobov privilegovaných žien v období st’ahovania národov na Severnom Kaukaze
}

\author{
Anna Mastykova
}

SÚHRN

Ciel'om príspevku je určit’ spoločenské postavenie hrobu bohatej ženy na pohrebisku Klin-Jar (oblast' Stavropol, Ruská federácia; obr. 1-6). Tento hrob, objavený náhodou počas stavebných prác, je výnimočný vd’aka nákrčníku, ktorý sa našiel v hrobovej výbave, čo je extrémne zriedkavý prípad medzi hrobmi ženskej elity z obdobia stahovania národov. Uplatnením princípov vypracovaných na základe západoeurópskych materiálov sú pre skúmaný región vyčlenené tri rôzne úrovne hrobov:

- Úroveň 1 zahŕňa hroby s najbohatšou a najvariabilnejšou hrobovou výbavou, ktorá obsahovala zlaté predmety, resp. prestížne artefakty súvisiace s „,vysokým postavením“, ako aj vzácne importované predmety. Dôležité je, že táto úroveň ženských hrobov sa na základe zloženia hrobovej výbavy delí na dve kategórie: kategóriu 1a a 1b. Kategória 1a zahŕňa ženské hroby, ktoré okrem zlata obsahovali najmä predmety prislúchajúce vysokému postaveniu. Kategóriu $1 b$ tvoria ženské hroby so zlatými predmetmi, avšak bez predmetov náležiacich vysokému spoločenskému postaveniu.

- Úroveň 2 zahŕňa hroby s ozdobami populárnych typov, vyrobenými z lacných farebných kovov (bronz, zriedka striebro), v niektorých prípadoch zo železa. Dôležitými artefaktmi v týchto hroboch sú najmä sklenené a kamenné koráliky.

- Úroveň 3 zahŕňa hroby neurčitého datovania a bez kovových súčastí odevu.

Pokial' ide o obyvatel'stvo Severného Kaukazu známe z písomných zdrojov spravidla z neskoršieho obdobia, určit’ súvislost' stanovených úrovní s niektorými spoločenskými triedami by bola náročná úloha. Stále je však možné predpokladat', že podobne ako kdekolvek v Európe, vzácne hroby s bohatou výbavou úrovne 1 zodpovedajú vyššej spoločenskej vrstve, početné hroby s „bežným“ súborom ozdôb úrovne 2 zodpovedajú strednej triede a napokon, hroby úrovne 3 patria nižšie postaveným členom spoločnosti (niektorým kategóriám detí, sociálne odkázaným jedincom, marginálnym skupinám a pod.). Ženský hrob na pohrebisku Klin-Jar je jediný v centrálnej zóne Severného Kaukazu, zodpovedá vyčlenenej kategórii 1a.

„Vznešený“ ženský odev európskeho barbarika z obdobia st’ahovania národov takmer vôbec neobsahoval nákrčníky, s výnimkou nálezu ženského hrobu v Leviciach-Kusej Hore a ešte jedného v Boľšom Kamenci. K nákrčníku z Klin-Jar poznáme zatial' len dve paralely, obe zo skupiny „kniežacích“ nálezov z obdobia stahovania národov vo východnej a strednej Európe: Wrocław-Rędzin a Bol’̌soj Kamenec (obr. 7: 1, 2). Pozlátený nákrčník zo ženského hrobu na pohrebisku Klin-Jar má oválny zlatý medailón vykladaný do geometrických vzorov (obr. 4: 1). Patrí k predmetom s neskororímskou tradíciou (obr. 8). Možno boli tieto ozdoby vyrobené v tej istej stredomorskej alebo blízkovýchodnej dielni a odrážajú tak bežnú stredomorskú módu. Vzácny nákrčník s medailónom vykladaným do geometrických vzorov zo ženského hrobu v Klin-Jar bol zjavne vyhotovený na nadpriemernej úrovni, čo naznačuje vysoké spoločenské postavenie majitel'ky. Je tiež dôležité, že tento hrob bol odkrytý na pohrebisku v oblasti Piatigorska, kde bolo v 5. a 6. stor. pravdepodobne mocenské centrum severokaukazských Alanov a poloha samotná, s pohrebiskom a ned’alekou opevnenou osadou, tam zaujíma významné miesto. V závere je dôležité zdôraznit', že móda vyšších spoločenských vrstiev Východorímskej ríše mala rozhodujúci vplyv na utváranie kultúry barbarskej šlachty na Severnom Kaukaze v 5. a 6. stor. 
